Nguyen, T. T. D. (2020). An Empirical Study on the Impact of Sustainability Reporting on Firm Value.

Journal of Competitiveness, 12(3), 119-135. https://doi.org/10.7441/joc.2020.03.07

\title{
AN EMPIRICAL STUDY ON THE IMPACT OF SUSTAINABILITY REPORTING ON FIRM VALUE
}

\section{- Thi Thuc Doan Nguyen}

\begin{abstract}
Value relevance is an attractive exploratory topic for firms due to its influence on a firm's competitiveness. Investigating potential factors that have an impact on firm value can provide management with the insights in how to enhance value. The aim of this paper is to explore the association between sustainability reporting and firm value to gain an awareness of the value relevance of sustainability disclosures. The study concentrates on large listed German firms as research objects to reduce the influence of firm size, legislation and geographic differences. Moreover, instead of observing diverse sustainability reporting guidelines in one research, this paper focuses on the current most popular guidance, the Global Reporting Initiative (GRI). With this focus, it is more likely to achieve a relevant comparability among the firms' sustainability reporting. This concentration also leads to the main research question of whether large listed German firms which have a higher adherent level to GRI guidance tend to have greater firm value. The research applies Multiple Regression to test the above relationship by involving 485 observations from 97 large listed German firms within the research period from 2013 to 2017. Along with the main model, a robustness test was performed to explore the connection in the context of a four-month period after the year-end deadline to issue sustainability reports in accordance with German Law. The findings indicate a significant negative relation between firm value and a firm's GRI adherent level of sustainability reporting.
\end{abstract}

Keywords: GRI adberent status, firm value, sustainability reporting

JEL Classification: G32, M14, M49, Q56

Received: November, 2019

1st Revision: April, 2020

Accepted: June, 2020

\section{INTRODUCTION}

Although sustainability reporting has become more significant over the past decades, the validity of research on how sustainability reporting associates with market value remains uncertain and incomplete. The development of corporate environmental and social reports has led to the recent popularity of sustainability reporting (Jones et al., 2016; Uyar, 2016). This prevalence has attracted investor recognition of sustainability reporting (Cormier \& Magnan, 2007). With this increasing awareness, investors are more likely to favor firms with better sustainability report- 
ing when making investing decisions (Cormier et al., 2009). In addition, awareness of the public relating to corporate social and environmental issues has required firms to disclose their efforts and actions being taken on these issues. These information transparencies meet the needs of many stakeholders, including shareholders (Jamali, 2008; Wang \& Li, 2015). However, whether investing in sustainability reporting facilitates firm value remains questionable (Cahan et al., 2016), and the impact of sustainability reporting on firm value is still not clear (Margolis et al., 2007).

The purpose of the present study is to test the effect of sustainability disclosure on firm value. In order to lessen the influence of distracting factors, this paper focuses on a specific country to reduce the inconsistent factors relating to firm culture, geography and legislation among different countries. The paper also concentrates on large listed companies to achieve consistency in firm size and regulation involving a certain type of companies. In addition, this research also aims to discover the effect of industrial factors on the relation between firm value and sustainability disclosures. Industry is divided into sensitive and friendly to environment, as firm sustainability transparency is likely diverse in these two types of industries. These disclosures can be seen as a legitimating approach for firms in sensitive industries. The paper seeks to enhance the stakeholder perceptions of the possible factors, mainly those concerning sustainability disclosures that may influence firm value. The outcomes may help to explore the investor behaviors regarding firm sustainability performance, so that a firm's management can form appropriate policies toward sustainability activities to attract investments and improve competitiveness.

Large listed firms in Germany have been chosen as research objects, as Germany is considered to be a pioneer country in sustainability reporting development in Europe. According to Directive 2014/95/EU, the German Bundestag set legislation to enhance firm transparency in non-financial perspectives. Mandatory reporting is required of large companies which have more than 500 employees and more than EUR 20 million in total balance sheets, or more than EUR 40 million of revenues. The regulation is expected to have an impact on approximately 550 companies in Germany (Kluge \& Sick, 2016). Since the beginning of the 2017 financial year these companies have been required to publish their sustainability reporting.

With the varieties of guidance norms on reporting sustainability performance, it is necessary to focus on a specific set of guidelines to evaluate the impact of sustainability reporting on firm value. Each set may have a different focus and a divergent framework from other sets. As a result, this may lead to the misunderstanding of the quality of sustainability reporting, which, in turn, causes results to be misinterpreted when investigating its impact on firm value. Moreover, large listed German companies can currently choose suitable guidelines as they strive to prepare sustainability reports. The flexibility in choosing appropriate guidelines and in disclosing nonfinancial information may lead to significant differences among firms' sustainability reporting. In order to lessen the dissimilarity and along with the use of the Global Reporting Initiative (GRI) in firms, the research takes GRI as a core guideline to examine the impact of GRI compliance of sustainability reporting on value of firms.

In addition to the popularity of GRI, the measurable and collectable GRI adherent level facilitates investigation into the influences of GRI compliance status of sustainability report on firms' value. The adherent status, which can be directly found in the GRI Database, includes the GRI 
Standards, G4, G3 and G3.1, Citing, and Non-GRI, and has become one of the main variables in testing the impact of sustainability reporting on firm value. The influence of sustainability reporting in this research is measured by firms' compliance level to GRI. This level is a means of revealing how transparent firms are through their sustainability report, so that it is likely that the higher level the firm has, the more transparency of the sustainability reports are. With the current concern about the influence of sustainability reporting on firm value, a research question is raised as to whether large listed German firms which have a higher adherent level to GRI tend to also show better firm value.

The paper is structured into four parts. The first section reviews relevant theories and literature relating to the topic. This part provides the main sources for developing the hypothesis. Then, research methodology and data are illustrated in section two. The following section presents the research outcomes and an applicable discussion. Lastly, the conclusion summarizes the previous contents, focusing on the research objective and main findings.

\section{THEORETICAL BACKGROUND}

Stakeholder theory and legitimacy theory are the two prevailing theories concerning the necessity of sustainability reporting in firm value. According to stakeholder theory, a firm's operations affect the benefits of both firms and other stakeholders. Consequently, a firm's actions and decision making should be based on the needs of all stakeholders. When the interests of these groups are taken into account, the improvement of risk estimation is facilitated, which then creates firm value for both investors and other stakeholders (Martinez-Ferrero \& FriasAceituno, 2013). As the guidelines are set up now, sustainability reporting requires a firm to release not only economic, environmental, social, and governance information but also the risks involved and solutions to deal with these risks (Ballou et al., 2006). As a result, sustainability reporting makes a critical contribution to both a firm's internal and external bodies. Moreover, a company can attain long-term support from its stakeholders when a board of directors adopts social responsibility practices, which can positively influence a firm's long-term value. Regarding legitimacy theory, it is perceived that firms have hidden responsibilities to its society. The need to behave as expected by society leads firms to make sustainability reports to demonstrate compliance to norms. Cho \& Patten (2007) also agree that sustainability disclosure can be used as a legitimizing tool. The legitimacy process requires firms to identify indicators with expectation regulations or other standards to measure their environmental and social performance to communicate with the society about the adherent status of the firm (Deegan \& Blomquist, 2006). Then legitimization is obtained only if an organization meets a minimum of the existing social values (Long \& Driscoll, 2008). When firms achieve transparent and appropriate sustainability reports, they have asserted their good performance in corporate social responsibility as well as in good business practices compliances. This can improve the stakeholders' perception of the firm's social responsibility performance and transparency. Consequently, a firm's value can be enhanced with a high level of stakeholder perceptions and support.

Sustainable reporting has become popular and compulsory in many countries. However, the impact of sustainability application and disclosures regarding firm value remain mixed these days. 
Positive relations were found in the research of Anam et al. (2011), who affirm that transparency and disclosure facilitate the evaluation quality of share price, which leads to firm value enhancement. In addition, Momin \& Parker (2013) demonstrate sustainability reporting as a tool to build or maintain the favorable reputation of a multinational organization. Eccles et al. (2011) confirm that well-performed sustainability firms achieve a 4.8 percent higher share price over the long-term period than their competitors. Therefore, it can be argued that greater sustainability disclosure tends to have a favorable impact on firm value. Beside investors, strong sustainability transparency, including firm social performance such as gender diversity and payment equality can also draw positive attention and help retain good employees (Cormier et al., 2011). This, in turn, positively influences firm value due to improved productivity, enhanced competitiveness, and reduced distributional conflicts. Positive influences of firm corporate sustainability reporting on financial value are also proved by Guidry \& Patten (2010) and Berthelot et al. (2012). Along with favorable influences, sustainability reporting has been shown adverse or there was no relationship with firm value in previous research. According to Mahoney et al. (2013), misleading and bias sustainability reporting exist due to firm's selected favorable sustainability performance disclosure. The failure in information transparency results in the assumption of a low quality firm as hidden information is likely to be considered as bad news. This, in turn, can negatively influence firm value. Further study has been carried out by Jones et al. (2007) on the association between sustainability disclosure and firm value in the long term. The authors also find unfavorable connections between these two variables. In the mean time, some studies have failed to find the relationships between corporate sustainability and firm value (Clarkson et al., 2010).

Different effects of corporate sustainability disclosure on firm value make it worthy to test the association with more tailored features of the sample. Major reasons for these diverse impacts come from a bulk of variables that may influence firm value and inconsistencies in measuring corporate sustainability. In order to tackle these issues, this research focuses on the observations in one country only, and in the same corporation size. Moreover, to avoid subjective opinion when evaluating sustainability report disclosures quality, this paper applies firm's adherent level to the GRI guidelines which can be found directly from the GRI database as a measurement for sustainability reporting.

In the light of mentioned theories, sustainability reporting can be considered to be a mean to perform the firms' commitment to stakeholders and society as for environmental and social issues. Once sustainable reporting achieves outstanding performance, it can reveal high responsibility of firm to other parties, and can assure sustainable development. This, in turn, can enhance firm's reputation and image. Based on this argument and the research question whether there is a connection between sustainability reporting and firm value, this research assumes that a firm which adheres to the GRI guidelines disclosures can enhance its value.

Hypothesis 1: Compliance with the GRI guidelines in reporting sustainability activities has a positive impact on German large listed firm value.

Jenkins (2006) states that sustainability performances are diverse depending on firms' sectors, therefore, the industry type is considered to be one of the significant impact factors of sustainability (Svensson et al., 2009). In fact, the amount of sustainability information to be disclosed is different depending on the type of firm industry. For instance, environmental information 
tends to be provided more by environmental sensitive firms whereas manufacturing firms tend to provide more sustainability information than firms in the sector of onces. Gamerschlag et al. (2010) discovers that companies in consumer and energy supplying industries disclose more sustainability facts and figures while those in services industry provide less information. Based on the arguments, this paper proposes that a firm under environmental pressure industries tends to enhance sustainability transparency, which leads to a high adherent level of sustainability reporting practices.

\section{RESEARCH METHODOLOGY AND DATA}

\subsection{Data collection}

With current five versions of GRI from G1 to GRI Standard, this research focuses on the most updated versions which include GRI-G3, GRI-G4, and GRI-Standard only. The five-year research period starts in 2013 when GRI-G4 is first issued. Since 2013, firms have stopped applying GRI-G1 and G2; however, GRI-G3 has still been applied commonly. Within the research period, 97 German large listed firms that have details of GRI adherent levels are collected from the GRI Report List Database each year. Therefore, a final sample for the whole period consists of 485 observations. There are twenty seven sectors observed in total, an thin which the average number of firms in each industry is about 3.5 firms. While some sectors include just one firm such as agriculture, water utilities, or healthcare products, the other has more firms operating in such as automotives and chemicals with nine firms in each sector, and financial sectors with thirteen firms. Firms in financial services, chemicals and automotives sectors occupy more than 30 percent of observed firms. These firms are then classified into environmental sensitive and friendly sectors for further analysis.

Referring to the classification of industry, this paper is based on the NAICS Codes which provide lists of environmentally sensitive industries. As for the German large firms listed in the sample, there are 27 industries in which according to NAICS Codes, 14 industries are identified as being in the pressure groups. These consist of Automotive (Codes: 42311, 42114), Aviation (481), Chemicals (325), Computers (334), Constructions and Construction materials (237), Equipment (335), Food and beverage products $(311,312)$, Household and personal products $(321,326,337)$, Logistics (481, 482, 484), Metal products (331), Textiles and Apparel (313, 314), and Energy and Energy Utilities (237). These 14 industries comprise 52 firms, and the environmentally friendly sectors include 45 firms.

Tab. 1 - List of environmental friendly (F) and sensitive (S) industries. Source: own research

\begin{tabular}{|l|l|l|l|}
\hline Industry & Type & Industry & Type \\
\hline Agriculture & F & Healthcare products & F \\
\hline Automotive & S & $\begin{array}{l}\text { Household and personal } \\
\text { products }\end{array}$ & S \\
\hline Aviation & S & Logistics & S \\
\hline Chemicals & S & Media & F \\
\hline
\end{tabular}




\begin{tabular}{|l|l|l|l|}
\hline Commercial services & F & Metal products & S \\
\hline Computers & S & Real Estate & F \\
\hline Conglomerates & F & Retailers & F \\
\hline Construction & S & Technology hardware & F \\
\hline Construction materials & S & Telecommunications & F \\
\hline Energy & S & Textiles and Apparel & S \\
\hline Energy Utilities & S & Tourism/ Leisure & F \\
\hline Equipment & S & Water Utilities & F \\
\hline Financial services & F & Others & F \\
\hline Food and Beverage products & S & & \\
\hline
\end{tabular}

The data for the dependent variable, share price at the year end and four months after the year end of each firm is gathered from Frankfurt, Xetra, Stuggart, Munich, Berlin, Dusseldorf, Hamburg, and Hannover Stock Exchange. The four-month after the year-end stock price is used to perform robustness test as the sustainability report can be issued after the end of a within financial year the defined limit period of four months (Federal Law Gazette, 2017). Regarding the independent variables, the GRI adherent level of each company is collected directly from the GRI Reports List Database. Along with the main variables, control variables which include firm profitability, firm size, firm leverage, firm age and external assurance status of sustainability report are gathered from firm annual reports, firm history, and the GRI Reports List Database.

\subsection{Variables measurement}

Tab. 2 - GRI adherent level ranking. Source: own research

\begin{tabular}{|c|c|c|c|c|c|}
\hline GRI Type & Adherent level & Index & GRI Type & Adherent level & Index \\
\hline Non-GRI & & 0 & \multirow{4}{*}{ G3.1 G3.1 } & $\mathrm{B}$ & 10 \\
\hline Citing GRI & & 1 & & $\mathrm{~B}+$ & 11 \\
\hline \multirow{6}{*}{ G3 } & Undeclared & 2 & & A & 12 \\
\hline & $\mathrm{C}$ & 3 & & $\mathrm{~A}+$ & 13 \\
\hline & $\mathrm{B}$ & 4 & \multirow{3}{*}{ G4 } & Undeclared & 14 \\
\hline & $\mathrm{B}+$ & 5 & & Core & 15 \\
\hline & $\mathrm{A}$ & 6 & & Comprehensive & 16 \\
\hline & $\mathrm{A}+$ & 7 & \multirow{3}{*}{ Standards } & GRI-referenced & 17 \\
\hline \multirow{2}{*}{ G3.1 } & Undeclared & 8 & & Core & 18 \\
\hline & $\mathrm{C}$ & 9 & & Comprehensive & 19 \\
\hline
\end{tabular}

To examine the association between firm value and sustainability reporting based on the GRI guideline, this paper applies Ohlson model which confers current firm share price to firm value. The GRI adherent level is ranked based on the GRI compliance status of firm sustainability reports (Fuente el al., 2017; Prado-Lorenzo et al., 2009). Four GRI versions which comprise GRI-G3, GRI-G3.1, GRI-G4, and GRI-Standards are involved in the research period from 2013 
to 2017. Since later versions are reviewed and amended to be more appropriate to implementing practices, it is likely that later versions provide more proper guidelines than previous versions. In each version, there are several adherence levels which determine how well firms followed theh hGRI guidelines such as A+, A, B+, B, C in GRI-G3 and G3.1, or core and comprehensive ones in GRI-G4 and Standards. As a result, a ranking can be identified to measure the GRI compliance status of the firms observed. In addition to the mentioned levels above, in each category, there is an undeclared status which means that even though firm sustainability reporting follows a specific indicated version, it is unclear which adherent level the report belongs to. This status as placed on the lowest level in each version. Aside the above four the GRI versions, from GRI database, there are also the GRI citing firms which refer to GRI guideline but have no GRI Content Index, and Non-GRI companies which do not belong any category from above. These two types of sustainability reports take the lowest rank of the GRI compliance status (Table 1).

Along with dependent and independent variables, the model employs five more control variables. First three control variables include firm performance, firm size, and firm age. Fama \& French (2006) and Thinggaard \& Damkier (2008) find that firm is steadily increased profitability is considered to be favorable information for investors' perception of a firm future and investors' decision-making process. Thus it can be seen as one factor to enhance firm value. Value relevance of firm profitability is also investigated by Gjerde et al. (2011) and Shamki \& Rahman (2012). As for the firm size, with the advantages of dealing stakeholders, an increasing market share, and employing economic scale, it is likely for large firms to have higher value (Serrasqueiro \& MacasNunes, 2008). In addition, large firms have usually been well organized and perform well, which leads to high possibility of achieving a fair price when issuing equity. Regarding the firm age, which is believed to be aligned with knowledge, abilities, skills and reputation (Agarwal \& Gort, 2002), is regarded as the third control variable. Due to the enhance reputation, it is believed that firm age has favorable association with firm value (Baker \& Kennedy, 2002). These three control variables are assumed to have a positive relation with firm value. The fourth control variable is firm leverage, which concerns risks when raising debt. These risks may consist of financial distress when a firm acquires a high debt level (Modigliani \& Miller, 1963), or interest conflict between shareholders and debt holders. Therefore, firm leverage is supposed to have an unfavorable impact on firm value. The last control variable is external assurance of sustainability report. Consistent with Simnett et al. (2009), sustainability reports have better quality when being audited by external parties. It can be stated that assurance of these reports can be seen as a mean to improve the reports' reliability. This can be seen as a positive influence on the stakeholder is perception of firm reputation, which then is presumed to have better influence on firm value.

Firm performance, firm size, firm age, and firm leverage are measured based on earlier research (Al-Najjar, 2014; Chen, 2007; Gurcharan, 2010; Coad et al., 2013). Referring to external assurance, dummy variables, of which 0 is for an unaudited sustainability report and 1 for an audited sustainability report, are utilized (Table 3). 
Tab. 3 - List of control variables measurement. Source: own research

\begin{tabular}{|l|l|}
\hline Variables & Measurement \\
\hline Firm performance & Net Income / Total assets (ROA) \\
\hline Firm size & Logarithm of total assets \\
\hline Firm age & Difference between the current year and founded year \\
\hline Firm leverage & Total debt / Total assets \\
\hline External assurance & 1: Yes, $0:$ No \\
\hline
\end{tabular}

\subsection{Research methods}

Initially, descriptive statistics is employed to describe basic features of the data. Then, correlation coefficient analysis is performed to avoid multi-collinear which may incur issues in interpreting coefficients due to duplicate information provided by some independent variables. Correlation coefficients express degree of the linear relationship between two random variables. A correlation coefficient of +1 and -1 indicates that two variables are perfectly related in a positive and negative linear sense respectively, and a correlation coefficient of 0 indicates that there is no linear relationship between the two variables. Multi-collinear exists where independent variables are strongly correlated with each other. Tabachnick \& Fidell (2001) state that multi-collinear may exist when correlation equals 0.7 or above. In addition, in order to avoid multi-collinear, tolerance of each variable is more than 0.2 or the variance inflation factor (VIF) of each variable is less than 10. Tolerance is defined as the possibility when the independent variable cannot interpret the dependent variable in the research model. Therefore, the lower of tolerance value is, the higher possibility for multi-collinear to be incurred. Meanwhile, VIF is the inverse of tolerance, hence, the impact on multi-collinear is opposite from tolerance.

Multiple Regression is applied to test the hypothesized relationship between one dependent variable and more than one independent variable. All variables in the tested model are numerical; therefore, Multiple Regression is considered to be an appropriate method. Along with the main model, the robustness test is performed to investigate the relationship between sustainability reporting and firm value, in which firm value is measured by the four-month after year-end share price instead of the year-end price as in the main model. The robustness test is conducted due to the four-month period deadline set by German law for firms to disclose their sustainability reports. In addition, companies in environmentally sensitive and friendly sectors are collected for running Multiple Regression to find the relationship between firm value and sustainability reporting in each sector. All these analyses and regressions are performed by using STATA statistical software.

The equation of Multiple Regression model is formulated as follows:

Shareprice $_{i t}=\beta_{0}+\beta_{1} S_{i t}+\beta_{2}$ Performance $_{i t}+\beta_{3}$ Size $_{i t}+\beta_{4}$ Age $_{i t}+\beta_{5}$ Leverage $+\beta_{6}$ Assurance $_{i t}+\varepsilon$

The robustness test with the four-month after year-end share price:

Shareprice $_{i(t+4)}=\beta_{0}+\beta_{1} S R_{i}+\beta_{2}$ Performance $_{i}+\beta_{3}$ Size $_{i}+\beta_{4}$ Age $_{i}+\beta_{5}$ Leverage $_{i}+\beta_{6}$ Assurance $_{i t}+\varepsilon$ 
In which: SR represents the GRI compliance in reporting sustainability activities; $i$ is the number of observations; $\mathrm{t}$ is the year of data from 2013 to 2017; $\beta_{0}$ is constant; $\beta_{1,2,3,4,5,6}$ are estimated coefficients of the explanatory variables; and $\varepsilon$ is an error term.

\section{RESULTS AND DISCUSSION}

\subsection{Descriptive statistics and correlation coefficient analysis}

The year-end share prices of the observed firms in the research period are significantly diverse with the highest and lowest share prices standing at $€ 728$ and $€ 0.54$ respectively. Among 485 observations, around 33\% firms have share prices beyond the average price of $€ 68$ and all firms' share prices fluctuate during the research period. As for the GRI application, from 2013 to 2017, GRI-G4 has been applied the most, having 193 sustainability reports based on it. In the meantime, the earliest version GRI-G3 and the lasted version GRI-Standards have 35 and 39 reports, following them correspondingly. The GRI citing has been utilized the least by only 11 firms. As for external assurance, 175 observed sustainability reports are audited by third parties which occupy about $36 \%$ of the whole sample. In addition, the researched firms are quite old with an average firm age of nearly 81 years.

Table 4 shows correlation results and the VIF value of all variables in the main model. As no correlation is above 0.7 and no VIF value is more than 10 as indicated by Tabachnick \& Fidell (2001), it can be stated that no multi-collinear issue incurs in the model. The correlation matrix also demonstrates significant associations between firm value and the GRI compliance, firm performance, firm size, and firm age and external assurance of sustainability reports. The only insignificant connection is between firm value and firm leverage. Regarding the association among independent variables, it is likely that larger firms, high leverage firms, and firms which have external audit on their sustainability reports tend to highly comply with GRI. In addition, the larger firms are the higher possibility to earn profit. Lastly, larger firms usually come with a higher debt and have the sustainability report audited.

Tab. 4 - Correlation matrix. Source: own research

\begin{tabular}{|l|l|l|l|l|l|l|l|l|}
\hline Variables & 1 & 2 & 3 & 4 & 5 & 6 & 7 & VIF \\
\hline 1. Share price & 1 & & & & & & & \\
\hline 2. GRI compliance & $.150^{*}$ & 1 & & & & & & 1.35 \\
\hline 3. Firm performance & $.121^{*}$ & -.017 & 1 & & & & & 1.24 \\
\hline 4. Firm size & $.179 *$ & $.302^{*}$ & $-.188^{*}$ & 1 & & & & 1.52 \\
\hline 5. Firm age & $.124^{*}$ & .031 & .022 & .039 & 1 & & & 1.00 \\
\hline 6. Leverage & -.059 & $.100^{*}$ & -.430 & $.513^{*}$ & .011 & 1 & & 1.60 \\
\hline 7. External assurance & $.113^{*}$ & $.473^{*}$ & .046 & $.294^{*}$ & -.026 & .062 & 1 & 1.38 \\
\hline
\end{tabular}

* Correlation is significant 


\subsection{Regression analysis}

The research performs Cameron and Trivedi's decomposition of IM-test and retrieves the p" value of heteroscedasticity, skewness, and kurtosis of $0.2981,0.5179$, and 0.4253 respectively. These results indicate that assumptions of homoscedasticity, symmetry, and normal kurtosis are satisfied with the implementing model. The regression results in Table 5 demonstrate the p-value of 0.034 with the coefficient of -0.435 , which indicates a negative significant relationship at the $5 \%$ level between firm share price and firm's compliance with the GRI guideline in reporting sustainability performance. This indicates that firm sustainability reports which have higher GRI adherent levels tend to have a lower share price than others. The significant association between the share price and GRI compliance in reporting sustainability activities is inconsistent with the hypothesis 1 . This outcome has rejected the association between firm value and firm compliance with GRI in reporting sustainability performance as proved by previous research (Anam et al., 2011; Berthelot et al., 2012; Guidry \& Patten, 2010; Middleton, 2015).

Tab. 5 - Empirical results for the main model. Source: own research

\begin{tabular}{|l|l|l|l|}
\hline Variables & Coefficients & $\mathrm{t}$ value & $\mathrm{P}$ value \\
\hline GRI Compliance & $-.435^{* *}$ & -2.12 & 0.034 \\
\hline Firm performance & $.479 * *$ & 2.03 & 0.043 \\
\hline Firm size & 7.520 & 0.95 & 0.340 \\
\hline Firm age & $4.81^{* * *}$ & 7.28 & 0.000 \\
\hline Firm leverage & .288 & 1.37 & 0.171 \\
\hline External assurance & $7.56^{* *}$ & 2.22 & 0.027 \\
\hline
\end{tabular}

* Significance at the $10 \%$ level, ** Significance at the 5\% level, *** Significance at the $1 \%$ level.

A negative relationship between firm value and GRI adherent status of firm sustainability reporting has been supported by agency theory and slack resources theory. According to agency theory, investing in corporate social responsibility wastes company resources as it tends to gain management reputation by using companies' resources at shareholder expenses (Barnea \& Rubin, 2010; Surroca et al., 2010). In the meantime, slack resources theory asserts that spending on corporate social responsibility activities leads to firm value deterioration since corresponding gained income cannot overcome this expenditure and concentrating on these activities absorb managements' focus on firm goals (Campbell, 2007).

An unfavorable association between firm value and the firm's compliance with the GRI guideline in reporting sustainability performance has also been demonstrated in previous research. Determinations of whether sustainability reporting enhances a firm reputation, which then positively influences firm value, is unambiguous. The reasons for this ambiguity may come from incomplete sustainability reporting, along with self-centeredness and insincerity according to Gray (2006), Unerman et al. (2007), Aras \& Crowther (2009) respectively. Luo et al. (2012) also argue that corporate sustainability reporting information may not reveal a firm's actual activities. At the same time, high quality sustainability reporting impairs shareholder awareness of a company's future cash flow risks (Bachoo et al., 2013), which in turn can harm shareholder value. 
As for control variables, the criteria of a firm, including firm performance and firm age have a favorable significant impact on firm share price, with the p-value of 0.043 and 0.000 respectively. This means firm share price is likely to increase when a firm performs better and is founded earlier. However, the regression results find no relation between firm size, firm leverage and firm share price. As for the external assurance of sustainability report, a positive significant association has been found with firm value at the p-value of 0.027 and coefficient of 7.56 . This confirms the importance of third-party audits on a firm's sustainability report, as it is likely that the share value is higher if these reports are audited. To sum up, these outcomes are consistent with the assumptions stated above for most of the control variables except for firm size and firm leverage.

\subsection{Robustness test results and discussion}

By replacing the year-end share price by the four-month after year-end share price in the main model, the association between firm value and firm GRI-compliance status of sustainability report maintains an unfavorable significance at the $1 \%$ level with the coefficient of -0.632 . This result again confirms the result that investing in sustainability activities and having a high adherent status in preparing high quality sustainability reporting tend to impair shareholder wealth. As for the control variables, firm performance, firm age and external assurances, there remains the same positive significant association with firm value as in the main model. In addition, the outcomes still show no connection between firm age, firm leverage and the dependent variable.

Tab. 6 - Empirical results for the robustness test. Source: own research

\begin{tabular}{|l|l|l|l|}
\hline Variables & Coefficients & t value & P value \\
\hline GRI Compliance & $-.632^{* * *}$ & -2.61 & 0.010 \\
\hline Firm performance & $.645^{* *}$ & 2.31 & 0.022 \\
\hline Firm size & 2.780 & 0.30 & 0.766 \\
\hline Firm age & $5.38^{* * *}$ & 6.86 & 0.000 \\
\hline Firm leverage & .410 & 1.65 & 0.101 \\
\hline External assurance & $11.12^{* * *}$ & 2.76 & 0.006 \\
\hline
\end{tabular}

* Significance at the $10 \%$ level, ** Significance at the 5\% level, *** Significance at the $1 \%$ level.

\subsection{Complementary results and discussion}

485 firms were divided into two groups, which include 52 environmentally sensitive firms and 45 environmentally friendly firms. Multiple Regression was performed in these two-group data, with the results of the main model illustrated in Table 7. A robustness test for the four-month after year-end price is presented in Table 8. Industry influences cause the outcome of the association between firm value and GRI compliance in sensitive environmentally sectors to turn insignificant, while the significant status still remains for environmentally friendly industries. The insignificant relation between these two variables in environmentally sensitive sectors indicates that compliance with the GRI framework does not have any impact on changes of firm value. This outcome was also found in the previous research of Clarkson et al. (2010) and Qiu et al. (2014). 
Tab. 7 - Empirical results for industry divided into sensitive and friendly sectors. Source: own research

\begin{tabular}{|c|c|c|c|c|}
\hline \multirow[t]{2}{*}{ Variables } & \multicolumn{2}{|c|}{$\begin{array}{l}\text { Environmentally sensitive } \\
\text { industry }\end{array}$} & \multicolumn{2}{|c|}{$\begin{array}{l}\text { Environmentally friendly } \\
\text { industry }\end{array}$} \\
\hline & Coefficient & P-value & Coefficient & P-value \\
\hline GRI Compliance SR & -.282 & .414 & $-.476^{* *}$ & .034 \\
\hline Firm performance & .503 & .104 & $3.950 *$ & .073 \\
\hline Firm size & -.171 & .882 & $3.134 * *$ & .023 \\
\hline Firm age & $5.017 * * *$ & .000 & $3.980 * * *$ & .000 \\
\hline Firm leverage & .494 & .125 & .194 & .462 \\
\hline External & $2.746 * *$ & .027 & 3.517 & .340 \\
\hline
\end{tabular}

* Significance at the $10 \%$ level, ** Significance at the $5 \%$ level, *** Significance at the $1 \%$ level.

Tab. 8 - Robustness test for industry dived into sensitive and friendly sectors. Source: own research

\begin{tabular}{|c|c|c|c|c|}
\hline \multirow[t]{2}{*}{ Variables } & \multicolumn{2}{|c|}{$\begin{array}{l}\text { Environmentally sensitive } \\
\text { industry }\end{array}$} & \multicolumn{2}{|c|}{$\begin{array}{l}\text { Environmentally friendly } \\
\text { industry }\end{array}$} \\
\hline & Coefficient & P-value & Coefficient & P-value \\
\hline GRI Compliance SR & -.443 & .283 & $-.576^{* *}$ & .023 \\
\hline Firm performance & $.703^{*}$ & .057 & .981 & .101 \\
\hline Firm size & -6.757 & .625 & $3.590 * *$ & .015 \\
\hline Firm age & $5.722^{* * *}$ & .000 & $4.016^{* * *}$ & .000 \\
\hline Firm leverage & .575 & .135 & .471 & .115 \\
\hline External & $6.940 * * *$ & .002 & 3.016 & .469 \\
\hline
\end{tabular}

* Significance at the $10 \%$ level, ** Significance at the $5 \%$ level, *** Significance at the $1 \%$ level.

This research provides relevant implications for firms and standards setters. Firms may acknowledge how sustainability reporting impacts firm value, so that they can adjust the implementing process to be able to achieve both the firm's financial and non-financial aims. With the focus on the GRI guideline, a firm may also have a clearer perception of how compliance with a specific instruction can influence firm value. This in turn leads to sounder decisions by firms regarding the choice of appropriate standards and approaches in performing sustainability activities and reporting sustainability performance to best accomplish firm goals. As for standards setters, this research should provide a deeper understanding of the efforts of firms to perform and of how such effort affects their financial performance and value. Based on this, standards setters can assist and encourage firms to follow sustainability development by making more appropriate and supporting principles.

\section{CONCLUSION}

To attempt to resolve the inconsistency of previous research results on the relationship between 
firm value and sustainability reporting, this paper further investigates this association by narrowing down dissimilarity in the observation features. The paper concentrates on large listed German firms to lessen the impact of size, legislation and geography. Furthermore, with a growing number of standards available to provide instructions on how to report sustainability performance, this paper focuses on one standard only and examines the impact of implementing this standard on firm value.

Due to the popularity of the Global Reporting Initiative among the standards available, the GRI framework was selected to carry out the research. The paper concentrates on 97 German large listed firms each year within the research period from 2013 to 2017 with the structure of a 485-observation sample. In order to investigate the relationship between firm value and a firm's GRI compliance status in sustainability reporting, relevant information such as firm value, GRI adherent status of firm sustainability report and firm financial information was collected from eight stock exchanges in Germany, the GRI Report List Database, and the annual reports of firms. Multiple Regression was then applied to test the association for the main model and robustness model.

The study finds a negative significant association between firm value and a firm's GRI adherence level in reporting sustainability performance in both models. The result proved to be in opposition with the stated hypothesis, which means a higher adherence to GRI of firm sustainability reporting the lower value of firm share can be observed. The outcomes deny the favorable connection between these two variables generally put forth in the theoretical background. However, these outcomes are consistent with agency theory and slack resource theory, which claim that investing in sustainability activities wastes a firm's resources and harms shareholder wealth. Moreover, this unfavorable connection is also affirmed by previous research due to the uncertainty in enhancing firm reputation in terms of investing in sustainability activities. The association was also explored in relation to industrial impact by examining the influence of GRI compliance of a sustainability report on firm value in environmentally friendly and sensitive sectors. The outcomes reveal an insignificant relationship between firm value and firm's compliance with GRI in sensitive sectors, while a significant association remains the same in environmentally friendly sectors. To sum up, a strong attempt to comply to popular GRI guidelines in reporting sustainability performance does not necessary improve firm value in sensitive environmentally friendly industries. This research has limitations in terms of the investigation of the actual reasons for the negative association between firm value and GRI adherent sustainability report of large listed German firms. Therefore, future research on investigating the cause of these influences should be performed so that a firm can appropriately apply the available guidelines to be beneficial in terms of firm value while achieving sustainability goals.

\section{References}

1. Agarwal, R., \& Gort, M. (2002). Firm Production Life Cycles and Firm Survival. American Economic Review, 92 (1), 184-190. https://doi.org/10.1257/000282802320189221

2. Al-Najjar, B. (2014). Corporate Governance, Tourism Growth and Firm Performance: Evidence from Publicly Listed Tourism Firms in Five Middle Eastern Countries. Tourism Management, 42, 342-351. https://doi.org./10.1016/j.tourman.2013.09.008 
3. Anam, O. A., Fatima, A. H., \& Majdi, A. R. H. (2011). Effects of Intellectual Capital Information Disclosed in Annual Reports on Market Capitalization: Evidence from Bursa Malaysia. Journal of Human Resource, Costing and Accounting, 15 (2), 85-101. https://doi.org/10.1108/14013381111157328

4. Aras, G. \& Crowther, D. (2009). Corporate Sustainability Reporting: A Study in Disingenuity? Journal of Business Ethics, 87 (1), 279-88. https://doi.org/10.1007/s10551-008-9806-0

5. Bachoo, K., Tan, R., \& Wilson, M. (2013). Firm Value and the Quality of Sustainability Reporting. Australian Accounting Review, 23 (1), 64-72. https://doi.org/10.1111 /j.1835-2561.2012.00187

6. Baker, G. P., \& Kennedy, R. E. (2002). Survivorship and the Economic Grim Reaper. Journal of Law, Economics and Organization, 18 (2), 324-341. https://doi.org/10.1093/jleo/18.2.324

7. Ballou, B., Heitger, D. L., \& Landes, C. E. (2006). The Future of Sustainability Reporting. Journal of Accountancy, 202 (6), 65-78.

8. Barnea, A., \& Rubin, A. (2010). Corporate Social Responsibility as a Conflict between Shareholders. Journal of Business Ethics, 97 (1), 71-86. http://dx.doi.org/10.2139/ssrn

9. Berthelot, S., Coulmont, M., \& Serret, V. (2012). Do Investors Value Sustainability Reports? A Canadian Study. Corporate Social Responsibility and Environmental Management, 19 (6), 355-363. https://doi.org/10.1002/csr.285

10. Cahan, S. F., De Villiers, C., Jeter, D. C., Naiker, V., \& Van Staden, C. J. (2016). Are CSR Disclosures Value Relevant? Cross-country Evidence. The European Accounting Review, 25 (3), 579-611. https://doi.org/10.2139/ssrn.2321727

11. Campbell, J. (2007). Why Would Corporations Behave in Socially Responsible Ways? An Institutional Theory of Social Responsibility. Academy of Management Review, 32 (3), 946-967. https://doi.org/10.5465/amr.2007.25275684

12. Chen, M. H. (2007). Hotel Stock Performance and Monetary Conditions. International Journal of Hospitality Management, 26 (3), 588-602. https://doi.org/10.1016/j.ijhm.2006.05.003

13. Cho, C. H., \& Patten, D. M. (2007). The Role of Environmental Disclosures as Tools of Legitimacy: A Research Note. Accounting, Organization and Society, 32 (7), 639-647. https://doi. org/10.1016/j.aos.2006.09.009

14. Clarkson, P., Fang, X. H., Li, Y., \& Richardson, G. (2010). The Relevance of Environmental Disclosures for Investors and Other Stakeholder Groups: Are Such Disclosures Incrementally Informative? Retrieved March 6, 2018 from https://papers.ssrn.com/sol3/papers.cfm?abstract_ id $=1687475$.

15. Coad, A., Segarra, A., \& Teruel, M. (2013). Like Milk or Wine: Does Firm Performance Improve with Age?. Structural Change and Economic Dynamics, 24 (1), 173-189. https://doi.org/10.1016/j. strueco.2012.07.002

16. Cormier, D., Aerts, W., Ledoux, M. J., \& Magnan, M. (2009). Attributes of social and human capital disclosure and information asymmetry between managers and investors. Canadian Journal of Administrative Sciences, 26 (1), 71-88. https://doi.org/10.1002/cjas.89

17. Cormier, D., Ledoux, M. J., \& Magnan, M. (2011). The informational contribution of social and environmental disclosures for investors. Management Decision, 49 (8), 1276-1304. https://doi. org $/ 10.1108 / 00251741111163124$ 
18. Cormier, D., \& Magnan, M. (2007). The revisited contribution of environmental reporting to investors' valuation of a firm's earnings: an international perspective. Ecological Economics, 62 (3), 613-626. https://doi.org/10.1016/j.ecolecon.2006.07.030

19. Deegan, C., \& Blomquist, C. (2006). Stakeholder influence on corporate reporting: an exploration of the interaction between WWF-Australia and the Australian minerals industry. Accounting, Organization, and Society, 314, 343-372

20. Eccles, R. G., \& Serafeim, G. (2011). Leading and Lagging Countries in Contributing to a Sustainable Society. Harvard Business School Working Knowledge: Boston.

21. Fama, E. F., \& French, K. R. (2006). Profitability, investment and average returns. Journal of Financial Economics, 82 (3), 491-518. https://doi.org/10.1016/j.jfineco.2005.09.009

22. Federal Law Gezette. (2017). Law to strengthen the non-financial reporting of companies in their situation and group management reports. In: CSR Directive Implementation Act. 20, 802-814. Retrieved April 8, 2018 from https:/www.bgbl.de/xaver/bgbl/ start.xav?start $=\% 2 \mathrm{~F} \% 2 \mathrm{~F} * 05 \mathrm{~B} \% 40$ attr_id $\% 3 \mathrm{D} \% 27 \mathrm{bgbl117s} 0827 . \mathrm{pdf} \% 27 \% 5 \mathrm{D} \#$ bgbl__\%2F\%2F*05B\%40attr_id\%3D\%27I_2017_20_inhaltsverz\%27\%5D__1569449473090

23. Fuente, J. A., Gacia-Sanchez, I. M. \& Lozano, M. B. (2017). The Role of the Board of Directors in the Adoption of GRI Guidelines for the Disclosure of CSR Information. Journal of Cleaner Production, 141, 737-750. https://doi.org/10.1016/j.jclepro.2016.09.155

24. Gamerschlag, R., Möller, K., \& Verbeeten, F. (2010). Determinants of voluntary CSR disclosure: empirical evidence from Germany. Review of Managerial Science, 5 (2), 233-262. https://doi. $\operatorname{org} / 10.1007 / \mathrm{s} 11846-010-0052-3$

25. Gjerde, Ø., Knivsfl ${ }^{\circ}$, K-H., \& Sættem, F. (2011). The value relevance of financial reporting in Norway 1965-2004. Scandinavian Journal of Management, 27,113-128. http://dx.doi.org/10.2139/ ssrn. 962051

26. Gray, R. (2006). Social, Environmental and Sustainability Reporting and Organisational Value Creation? Whose value? Whose Creation? Accounting, Auditing \& Accountability Journal, 19 (6), 793-819. https://doi.org/ 10.1108/09513570610709872

27. Guidry, R. P., \& Patten, D. M. (2010). Market Reactions to the First-Time Issuance of Corporate Sustainability Reports: Evidence That Quality Matters. Sustainability Accounting, Management and Policy Journal, 1 (1), 33-50. https://doi.org/10.1108/20408021011059214

28. Gurcharan, S. (2010). A Review of Optimal Capital Structure Determinant of Selected ASEAN Countries. International Research Journal of Finance and Economics, 47, 32-43.

29. Jamali, D. (2008). A Stakeholder Approach to Corporate Social Responsibility: A Fresh Perspective into Theory and Practice. Journal of Business Ethics, 82 (1), 213-231. https://doi.org/ 10.1007A10551-007-9572-4

30. Jenkins, H. 2006. Small Business Champions for Corporate Social Responsibility. Journal of Business Ethics, 67 (3), 241-56. https://doi.org/10.1007/s10551-006-9182-6

31. Jones, P., Hillier, D., \& Comfort, D. (2016). Materiality and External Assurance in Corporate Sustainability Reporting: An Exploratory Study of Europe's Leading Commercial Property Companies. Journal of European Real Estate Research, 9 (2), 147-170. https://doi.org/10.1108/ JERER-07-2015-0027 
32. Jones, S., Frost, G., Loftus, J., \& Van Der Laan, S. (2007). An Empirical Investigation of the Market Returns and Financial Performance of Entities Engaged in Sustainability Reporting. Australian Accounting Review, 17 (1), 78-87. https://doi.org/ 10.1111/j.1835-2561.2007.tb00317.x

33. Kluge, N., \& Sick, S. (2016). Private economy with transparency to social engagement? To companies potentially affected by the CSR Directive Implementation Act. Retrieved April 8, 2018 from https://www.boeckler.de/pdf/p_mbf_report_2016_27.pdf

34. Long, B.S., \& Driscoll, C. (2008). Codes of ethics and the pursuit of organizational legitimacy: theoretical and empirical contributions. Journal of Business Ethics, 77, 173-189. https://doi.org/ 10.1016/j.aos.2005.04.001

35. Mahoney, L., Thorne, L., Cecil, L., \& Lagore, W. (2013). A Research Note on Standalone Corporate Social Responsibility Reports: Signaling or Greenwashing? Critical Perspectives on Accounting, 24 (4-5), 350-359. https://doi.org/10.1016/j.cpa.2012.09.008

36. Margolis, J. D., Elfenbein, H. A., \& Walsh, J. P. (2007). Does It Pay to Be Good? A MetaAnalysis and Redirection of Research on the Relationship between Corporate Social and Financial Performance. Ann Arbor, 1001, 48109-1234. https://doi.org/ 10.2139/ssrn.1866371

37. Martínez-Ferrero, J., \& Frías-Aceituno, J. V. (2013). Relationship between sustainable development and financial performance: International empirical research. Business, Strategy and the Environment, 24, 20-39. https://doi.org/10.1002/bse.1803

38. Modigliani, F., \& Miller, M. H. (1963). Corporate Income Taxes and the Cost of Capital: A Correction. The American Economic Review, 53, 433-443. Retrieved October 20, 2018 from https://www.jstor.org/stable/1809167?seq=1

39. Momin, M. A., \& Parker, L. D. (2013). Motivations for Corporate Social Responsibility Reporting by MNC Subsidiaries in an Emerging Country: The Case of Bangladesh. The British Accounting Review, 45 (3), 215-228. https://doi.org/ 10.1016/j.bar.2013.06.007

40. Prado-Lorenzo, J. M. \& Garcia-Sanchez, I. M. (2010). The Role of the Board of Directors in Disseminating Relevant Information on Greenhouse Gases. Journal of Business Ethics, 97 (3), 391-424. https://doi.org/10.1007/s10551-010-0515-0

41. Qiu, Y., Shaukat, A., \& Tharyan, R. (2014). Environmental and social disclosures: Link with corporate financial performance. The British Accounting Review, 48 (1), 1-15. http://doi. org/10.1016/j.bar.2014.10.007

42. Serrasqueiro, Z. S., \& Macasnunes, P. (2008). Performance and Size: Empirical Evidence from Portuguese SMEs. Small Business Economics, 31 (2), 195-217. https://doi.org/10.1007/s11187007-9092-8

43. Shamki, D. \& Rahman, A. A. (2012). Value relevance of earnings and book value: Evidence from Jordan. International Journal of Business and Management, 7 (3), 133-141. https://doi. org/10.5539/ijbm.v7n3p133

44. Simnett, R., Vanstraelen, A., \& Chua, W. F. (2009). Assurance on Sustainability Reports: An International Comparison. The Accounting Review, 84 (3), 937-967. https://doi.org/10.2308/ accr.2009.84.3.937 
45. Surroca, J., Tribo, J. A., \& Waddock, S. (2010). Corporate Responsibility and Financial Performance: The role of intangible resources. Strategic Management Journal, 31 (5), 463-490. https://doi.org/10.1002/smj.820

46. Svensson, G., Wood, G., Singh, J., \& Callaghan, M. (2009). Implementation, communication and benefits of corporate codes of ethics: an international and longitudinal approach for Australia, Canada and Sweden. Business Ethics: A European Review, 1 (4), 389-407. https://doi. org/10.1111/j.1467-8608.2009.01571.x

47. Tabachnick, B. G., \& Fidell, L. S. (2001). Using Multivariate Statistics. 4th edition. Allyn and Bacon: Boston.

48. Thinggaard,F., \& Damkier, J. (2008). Has financial statement information become less relevant? Longitudinal evidence from Denmark. Scandinavian Journal of Management, 24 (4), 375-387. https://doi.org/10.1016/j.scaman.2008.06.001

49. Unerman, J., Bebbington, J., \& O’Dwyer, B. (2007). Introduction to sustainability accounting and accountability. In Unerman, J., Bebbington, J. \& O’Dwyer, B. (Eds), Sustainability Accounting and Accountability, Routledge, New York: NY.

50. Uyar, A. (2016). Evolution of Corporate Reporting and Emerging Trends. The Journal of Corporate Accounting and Finance, 27 (4), 27-30. https://doi.org/10.1002/jcaf.22157

51. Wang, K. T., \& Li, D. (2015). Market Reactions to the First-Time Disclosure of Corporate Social Responsibility Reports: Evidence from China. Journal of Business Ethics, 138 (4), 661-682. https://doi.org/10.1007/s10551-015-2775-1

\section{Contact information}

Thi Thuc Doan Nguyen

Tomas Bata University in Zlin

Faculty of Management and Economics

Department of Finance and Accounting

Czech Republic

E-mail:dnguyen@fame.utb.cz.

ORCID: 0000-0003-4758-849X 